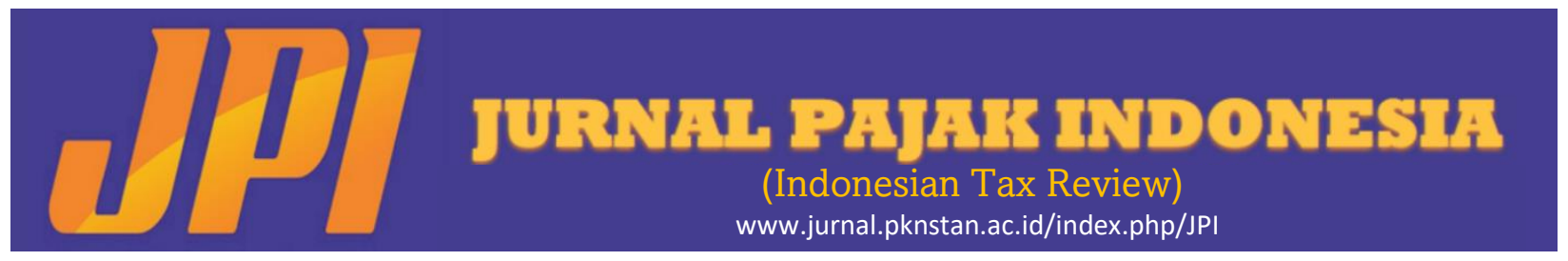

\title{
EFEKTIVITAS PELAKSANAAN PENAGIHAN PAJAK DI KPP PRATAMA DENPASAR BARAT PADA MASA PANDEMI COVID-19
}

\author{
I Made Adi Surya Jaya \\ Politeknik Keuangan Negara STAN \\ Supriyadi \\ Politeknik Keuangan Negara STAN \\ Alamat Korespondensi: priesoekarno@pknstan.ac.id
}

\section{INFORMASI ARTIKEL}

Diterima Pertama

[31102021]

Dinyatakan Diterima

[12112021]

KATA KUNCI:

Efektivitas, Penagihan Pajak, Masa Pandemi COVID-19

\section{ABSTRAK}

The COVID-19 pandemic has had an impact on Indonesia's economy. This can be seen from the decrease in state cash receipts from the taxation sector. One possible cause is the actions of tax collection that is not maximal. This study aims to determine the effectiveness of tax collection during the COVID-19 Pandemic (March-December 2020). Effectiveness is assessed based on the percentage rate of realization of disbursement of tax receivables resulting from tax collection actions. The analysis method used in this study, namely quantitative and qualitative method by utilizing tax collection data at KPP Pratama Denpasar Barat. The results showed that the percentage rate of effectiveness of tax collection during the COVID-19 pandemic (MarchDecember 2020) in KPP Pratama Denpasar Barat was considered ineffective. The effectiveness rate also decreased significantly compared to the previous two years. The decrease is due to the many obstacles due to the COVID-19 pandemic that KPP Pratama Denpasar Barat must face in carrying out tax collection actions.

Pandemi COVID-19 telah memberikan dampak terhadap perekonomian Indonesia. Hal ini terlihat dari menurunnya penerimaan kas negara dari sektor perpajakan. Salah satu kemungkinan penyebabnya, yaitu tindakan penagihan pajak yang tidak maksimal. Penelitian ini bertujuan untuk mengetahui tingkat efektivitas pelaksanaan penagihan pajak pada masa Pandemi COVID19 (Maret-Desember 2020). Efektivitas dinilai berdasarkan tingkat persentase realisasi pencairan piutang pajak yang dihasilkan dari tindakan penagihan pajak. Metode analisis yang digunakan dalam penelitian ini, yaitu metode kuantitatif dan kualitatif dengan memanfaatkan data penagihan pajak di Kantor Pelayanan Pajak Pratama Denpasar Barat. Hasil penelitian menunjukan bahwa tingkat persentase efektivitas penagihan pajak pada masa pandemi COVID-19 (Maret-Desember 2020) di KPP Pratama Denpasar Barat tergolong tidak efektif apabila dilihat dari realisasi pencapain target penagihan pajak. Tingkat efektivitas tersebut juga mengalami penurunan yang cukup signifikan dibandingkan dengan dua tahun sebelumnya. Penurunan tersebut diakibatkan oleh banyaknya hambatan-hambatan akibat pandemi COVID-19 yang harus dihadapi KPP Pratama Denpasar Barat dalam melakukan tindakan penagihan pajak. 


\section{PENDAHULUAN}

\subsection{Latar Belakang}

Pada bulan Maret 2020, World Health Organization (WHO) secara resmi mengumumkan Coronavirus Disease-2019 (COVID-19) sebagai pandemi global. Pandemi COVID-19 telah memberikan dampak, bukan hanya terhadap kesehatan suatu negara melainkan juga sisi perekonomian suatu negara. Adanya pandemi ini telah mengakibatkan perlambatan pertumbuhan ekonomi, baik secara global maupun nasional. Berdasarkan hasil survey Lembaga Ilmu Pengetahuan Indonesia (LIPI) menunjukan bahwa $94,69 \%$ usaha mengalami penurunan penjualan selama masa pandemi dan diperkirakan sebanyak $47,13 \%$ usaha mikro, kecil, dan menengah (UMKM) harus gulung tikar akibat pandemi COVID-19 (Lembaga IImu Pengetahuan Indonesia, 2020). Untuk meminimalisasi dampak perekonomian yang lebih parah, Pemerintah Indonesia merespon dengan mengeluarkan berbagai kebijakan. Salah satu kebijakan ekonomi yang diterbitkan Pemerintah Indonesia yaitu dari sektor perpajakan dengan memberikan berbagai insentif pajak terhadap wajib pajak.

Pemerintah Indonesia melalui Menteri Keuangan Republik Indonesia telah menerbitkan beberapa kali peraturan terkait dengan insentif perpajakan. Sampai dengan penelitian ini dibuat, setidaknya sudah empat kali peraturan terkait insentif perpajakan ini mengalami perubahan. Peraturan yang berlaku saat ini yaitu PMK Nomor 110/PMK 03/2020 mengatur tentang Insentif Pajak Untuk Wajib Pajak yang Terdampak Coronavirus Disease-2019.

Pemberian insentif pajak oleh pemerintah diharapkan mampu mengurangi beban wajib pajak dalam menjalankan kegiatan usahanya serta mampu menggerakan kembali roda perekonomian Indonesia di tengah pandemi. Namun, perlu disadari bahwa pemberian insentif ini hanya menguntungkan bagi wajib pajak yang terbilang patuh dalam menjalankan kewajiban perpajakan. Di sisi lain, adanya pandemi COVID-19 tentu juga memberikan dampak bagi wajib pajak yang mempunyai tunggakan pajak. Tunggakan pajak yang lama tidak dilunasi oleh wajib pajak akan menimbulkan adanya proses penagihan pajak.

Prinsipnya bahwa penagihan pajak dilakukan hanya untuk menagih tunggakan pajak yang dimiliki oleh wajib pajak. Namun, proses penagihan pajak yang tetap berjalan di masa pandemi justru bisa menimbulkan kontradiktif dengan prinsip keadilan pajak. Proses penagihan yang tetap berjalan memungkinkan dapat membuat banyak usaha wajib pajak akan gulung tikar karena harus melunasi seluruh tunggakan pajak. Hal ini membuat petugas pajak pun menjadi dilema. Di satu sisi, tidak adanya insentif penangguhan proses penagihan pajak membuat seluruh rangkaian proses penagihan pajak harus tetap dilaksanakan sesuai prosedur. Namun disisi lain pelaksanaan penagihan tunggakan pajak yang tetap berjalan akan berseberangan dengan tujuan dari adanya insentif pajak yang dikeluarkan oleh pemerintah. Adanya kontradiktif tersebut, dirasa akan berpengaruh terhadap efektivitas proses penagihan pajak itu sendiri.

Efektivitas penagihan pajak menjadi salah satu rencana strategis yang tertuang di dalam Keputusan Direktur Jenderal Pajak Nomor 95/PJ/2015 tentang Rencana Strategis Direktorat Jenderal Pajak tahun 2015-2019. Indeks Kinerja Utama (IKU) efektivitas proses penagihan itu sendiri dinilai berdasarkan persentase pencairan tunggakan/piutang pajak, yaitu perbandingan antara realisasi dengan target. Pada tahun 2018, efektivitas penagihan pajak secara nasional mencapai angka $156,61 \%$, sedangkan pada tahun 2019 hanya mencapai angka 126,45\% (Direktorat Jenderal Pajak, 2020). Terlihat bahwa selama dua tahun terakhir pada situasi ekonomi normal, efektivitas penagihan pajak secara nasional mengalami perubahan. Tentu pada masa pandemi seperti ini, efektivitas tersebut bisa saja kembali mengalami perubahan yang cukup signifikan.

Urgensi dari masalah efektivitas penagihan pajak di masa pandemi COVID-19, yaitu penting untuk bisa mengetahui apakah pelaksanaan proses penagihan pajak masih bisa tetap berjalan sesuai dengan tujuannya di tengah situasi ekonomi masyarakat yang sedang terpuruk. Penulis juga menyadari bahwa masalah efektivitas penagihan pajak di masa pandemi COVID-19 ini penting untuk dianalisis guna dijadikan sebagai bahan evaluasi pemerintah dalam pembuatan suatu kebijakan khususnya terkait proses penagihan pajak di masa pandemi.

Berdasarkan uraian-uraian diatas, penulis tertarik untuk melihat bagaimana efektivitas pelaksanaan proses penagihan pajak pada masa pandemi COVID-19 di salah satu Kantor Pelayanan Pajak Pratama di Kota Denpasar. Untuk itu penulis melakukan penelitian dengan judul "Efektivitas Pelaksanaan Penagihan Pajak di KPP Pratama Denpasar Barat Pada Masa Pandemi COVID-19".

\section{LANDASAN TEORI}

\subsection{Penelitian Terdahulu}

Penulis menemukan beberapa penelitian terdahulu yang membahas mengenai efektivitas penagihan pajak. Penelitian pertama yaitu jurnal administrasi bisnis yang berjudul "Analisis Efektivitas Pelaksanaan Penagihan Pajak Aktif Dengan Menggunakan Konsep Value For Money" yang ditulis oleh Ni Nyoman Vitria Anjarsari dan Naniek Noviari tahun 2017, fokus penulisan dari jurnal ini adalah bagaimana tingkat efektivitas penagihan pajak dengan surat teguran, surat paksa, dan juga surat perintah melaksanakan penyitaan (SPMP) dengan konsep value for money selama tahun 2010-2015 dengan lokasi penelitian di seluruh Kantor Pelayanan Pajak Pratama di Provinsi Bali.

Penelitian lain yang mempunyai fokus yang sama, yaitu Karya Tulis Tugas Akhir yang berjudul "Analisis Kontribusi dan Efektivitas Penagihan Pajak dengan Surat Paksa di KPP Pratama Semarang Selatan Tahun 2016-2018", karya tulis ini ditulis oleh Rido Dharma Putra pada tahun 2019. 
Fokus dari penulisan ini yaitu mengukur tingkat efektivitas pebagihan pajak dengan surat paksa, dan kontribusi penagihan dengan surat paksa terhadap penerimaan pajak selama tahun 2016-2018 di KPP Pratama Semarang Selatan.

Dari kedua penelitian tersebut, semua penulis melakukan penelitian di saat situasi normal dan tidak ada pandemi COVID-19 seperti saat ini. Selain itu, kedua penelitian tersebut tidak melakukan penelitian atas semua tindakan penagihan pajak, melainkan hanya sampai dengan penyampaian surat paksa. Oleh karena itu lah, penulis melakukan penelitian dan membuat Karya Tulis Tugas Akhir yang berjudul "Efektivitas Pelaksanaan Penagihan Pajak di KPP Pratama Denpasar Barat Pada Masa Pandemi COVID-19".

Dalam penulisan ini, penulis ingin mengetahui bagaimana persentase efektivitas proses penagihan pajak dalam mencairkan piutang pajak di lokasi penelitian yang berbeda dari penelitian sebelumnya, yaitu Kantor Pelayanan Pajak Pratama Denpasar Barat, serta pada situasi yang berbeda, yaitu selama masa Pandemi COVID-19 khususnya di tahun 2020. Tindakan penagihan pajak pada penelitian ini tidak hanya sampai dengan penyampaian surat paksa tetapi semua tindakan penagihan pajak sebagaimana diatur Undang-Undang PPSP. Selain itu juga, karena situasi dan keadaan yang berbeda dari tahun-tahun kemarin saat penelitian terdahulu dibuat, pada penelitian ini juga membahas hambatan-hambatan KPP Pratama Denpasar Barat dalam melakukan penagihan pajak selama masa pandemi COVID-19 dan upaya KPP Pratama Denpasar Barat untuk menyelesaikan hambatan tersebut.

\subsection{Teori/Konsep}

\subsubsection{Utang Pajak}

Rochmat Soemitro dalam Utara (2011) mendefinisikan utang pajak sebagai utang dalam pengertian sempit menurut hukum perdata, yaitu utang yang timbul secara khusus karena adanya perikatan atau perjanjian khusus, dalam hal ini merupakan undang-undang, yang mewajibkan debitur (warga negara) untuk membayar sejumlah uang kepada kreditur (negara). Utang pajak dapat timbul apabila telah terdapat peraturan yang mendasarinya dan juga apabila telah terpenuhinya sasaran pemajakan (tatbestand), yang terdiri dari keadaan-keadaan, peristiwa-peristiwa ataupun perbuatan-perbuatan tertentu. Jika dijabarkan lebih lanjut, timbulnya utang pajak dapat timbul karena dua teori/ajaran, yaitu ajaran formil dan ajaran materii.

Menurut ajaran formil, utang pajak timbul jika dan hanya jika dikeluarkan Surat Ketetapan Pajak (SKP) oleh pegawai pajak. Surat Ketetapan Pajak menjadi memiliki fungsi sebagai dasar dari seseorang memiliki utang pajak. Dalam ajaran materiil disebutkan bahwa utang pajak timbul jika dan hanya jika terdapat sesuatu hal yang dapat menimbulkan timbulnya utang pajak. Sesuatu hal tersebut berupa rangkaian peristiwa-peristiwa, keadaan-keadaan, maupun perbuatan-perbuatan tertentu (tatbestand).
Sehingga menurut ajaran ini, utang pajak timbul tidak harus menunggu dikeluarkan/diterbitkannya Surat Ketetapan Pajak (SKP) oleh pegawai pajak seperti halnya pada ajaran formil.

\subsubsection{Penagihan Pajak}

Penagihan pajak adalah serangkaian tindakan agar penanggung pajak melunasi utang pajak dan biaya-biaya penagihan pajak dengan menegur atau memperingatkan, melaksanakan penagihan seketika dan sekaligus, memberitahukan Surat Paksa, mengusulkan pencegahan, melaksanakan penyitaan, melaksanakan penyanderaan, dan menjual barang-barang yang telah disita. Soemitro (1991) dalam bukunya yang berjudul Pengantar Singkat Hukum Pajak juga mendefinisikan penagihan pajak sebagai suatu perbuatan yang dilakukan oleh Direktorat Jenderal Pajak kepada wajib pajak karena wajib pajak tersebut tidak memenuhi ketentuan Undang-Undang Perpajakan khususnya mengenai pembayaran utang pajak.

Tindakan penagihan pajak di dalam UndangUndang Penagihan Pajak dengan Surat Paksa tidak dibedakan menjadi istilah penagihan pajak pasif dan penagihan pajak aktif. Namun dari beberapa literatur dan kajian, banyak yang membedakan proses penagihan pajak menjadi dua, yaitu proses penagihan pajak pasif dan proses penagihan pajak aktif. Penagihan pajak pasif adalah proses penagihan pajak kepada wajib pajak oleh petugas pajak dengan menggunakan Surat Tagihan Pajak (STP), Surat Ketetapan Pajak Kurang Bayar (SKPKB), Surat Ketetapan Pajak Kurang Bayar Tambahan (SKPKBT), SK Pembetulan, SK Keberatan, Putusan Banding yang membuat nilai pajak yang terutang menjadi lebih besar dari sebelumnya (Suandy, 2011). Sedangkan penagihan pajak aktif merupakan suatu rangkaian kegiatan yang merupakan tindak lanjut dari proses penagihan pajak pasif dimana dalam hal ini petugas pajak atau fiskus tidak hanya menagih dengan menerbitkan produk hukum saja tetapi petugas pajak/fiskus lebih berperan aktif untuk menagih utang pajak kepada wajib pajak dengan dimulai dari menerbitkan surat teguran, menyampaikan surat paksa, melakukan penyitaan, pencegahan atau penyanderaan terhadap wajib pajak sampai dengan pelelangan atas barangbarang sitaan wajib pajak.

Penagihan pajak dilakukan oleh Jurusita Pajak. Jurusita Pajak yang akan menjadi pelaksana tindakan penagihan pajak yang dimulai dari penerbitan surat teguran, penyampaian surat paksa, penyitaan, penyanderaan, dan pelelangan atas hasil sita. Penerbitan surat teguran dapat dilakukan oleh petugas pajak dalam jangka waktu 7 hari sejak jatuh tanggal jatuh tempo pembayaran surat ketetapan pajak. Surat teguran memberikan jangka waktu maksimal 21 hari agar wajib pajak segera melunasi utang-utang pajaknya. Penyampaian surat teguran dapat disama artikan juga dengan suatu somasi yaitu hanya memberikan suatu peringatan kepada suatu pihak lain untuk menuruti apa yang dikehendaki oleh pemberi somasi. 
Setelah diterbitkan surat teguran kepada wajib pajak, apabila dalam jangka waktu 21 hari tersebut belum ada pelunasan pajak oleh wajib pajak, maka tindakan penagihan pajak aktif akan dilanjutkan ke proses berikutnya yaitu penerbitan dan penyampaian surat paksa. Surat paksa merupakan surat yang diterbitkan Direktorat Jenderal Pajak untuk memerintahkan penanggung pajak untuk melunasi utang pajak serta biaya penagihan pajak. Direktorat Jenderal Pajak dalam menerbitkan surat paksa memerintahkan dua hal kepada penanggung pajak, yaitu agar penanggung pajak melunasi utang pajak sekaligus biaya penagihan pajak dalam jangka waktu $2 \times 24$ jam sejak surat paksa itu disampaikan serta perintah kepada Jurusita Pajak untuk melanjutkan pelaksanaan surat paksa dengan melakukan penyitaan terhadap barang-barang milik penanggung pajak jika dalam jangka waktu 2 × 24 jam penanggung pajak belum juga melunasi utang pajak.

Direktur Jenderal Pajak yang telah menerbitkan surat paksa dapat menerbitkan Surat Perintah Melaksanakan Penyitaan (SPMP) apabila dalam jangka waktu 2 kali 24 jam sejak tanggal surat paksa diberitahukan kepada wajib pajak atau penanggung pajak belum ada pelunasan utang pajak yang dilakukan oleh wajib pajak. Penyitaan merupakan tindakan Jurusita Pajak untuk menguasai barang penanggung pajak guna dijadikan jaminan untuk melunasi utang pajak sesuai dengan peraturan perundang-undangan. Apabila setelah melewati jangka waktu 14 hari wajib pajak masih belum juga melunasi utang pajak yang dimilikinya, maka tindakan penagihan dilanjutkan dengan tindakan lelang atas barang-barang sitaan wajib pajak. Lelang sendiri merupakan setiap penjualan barang dimuka umum yang dilakukan dengan cara penawaran harga secara lisan dan/atau tertulis melalui usaha pengumpulan peminat atau calon pembeli.

\subsubsection{Efektivitas}

Efektivitas merupakan ukuran mengenai seberapa baik atau seberapa tepat sasaran atau rencana yang telah ditetapkan dapat direalisasikan (Alijoyo, 2000).

Dalam sektor perpajakan khususnya dalam proses penagihan pajak, efektivitas diukur dengan membandingkan antara target utang pajak yang akan dicairkan dengan realisasi atau jumlah yang benarbenar berhasil dilakukan tindakan penagihan pajak. Sesuai dengan Keputusan Direktur Jenderal Pajak Nomor 95/PJ/2015 tentang Rencana Strategis Direktorat Jenderal Pajak tahun 2015-2019, dijelaskan bahwa indeks kinerja utama untuk mengukur efektivitas penagihan pajak yaitu diukur dengan persentase realisasi pencairan utang pajak dibandingkan dengan target yang telah ditetapkan, sehingga proses penagihan pajak akan dikatakan sepenuhnya efektif jika realisasi pencairan tunggakan/piutang pajak memenuhi target.

Namun selain itu, terdapat indikator lain untuk mengklasifikasikan pada tingkat persentase berapa kinerja keuangan dapat dikatakan efektif ataupun bahkan sangat efektif. Berdasarkan Kepmendagri No
690.900.327 tentang Pedoman Penilaian Kinerja Keuangan Tahun 1996 maka tingkat efektivitas dapat dikategorikan sebagai berikut.

Tabel 1. Kategori Efektivitas

\begin{tabular}{|l|l|}
\hline $\begin{array}{l}\text { Persentase } \\
\text { Efektivitas }\end{array}$ & Kategori \\
\hline$>100 \%$ & Sangat Efektif \\
\hline $90-100 \%$ & Efektif \\
\hline $80-90 \%$ & Cukup Efektif \\
\hline $60-80 \%$ & Kurang Efektif \\
\hline$<60 \%$ & Tidak Efektif \\
\hline
\end{tabular}

Sumber: Kepmendagri No 690.900.327

\section{METODE PENELITIAN}

Desain penelitian yang digunakan penulis untuk melakukan penelitian yaitu metode campuran. Metode campuran (mixed methods) adalah suatu metode penelitian yang mengkombinasikan atau menggabungkan antara metode kuantitatif dengan metode kualitatif yang digunakan secara bersama-sama dalam suatu kegiatan penulisan, sehingga diperoleh data yang lebih komprehensif, valid, reliabel, dan objektif (Sugiyono, 2011).

Jenis data yang digunakan dalam penelitian ini adalah data primer dan data sekunder. Di dalam penelitian ini, hasil wawancara penulis dengan narasumber yaitu pegawai pajak Bagian Seksi Penagihan KPP Pratama Denpasar Barat khususnya Jurusita Pajak akan menjadi data primer. Sedangkan, data sekunder dalam penelitian penulis yaitu dokumen-dokumen berkaitan penagihan pajak yang dimiliki dan disediakan oleh KPP Pratama Denpasar Barat serta literatur-literatur lain yang berkaitan dengan topik penelitian.

Dalam melakukan pengumpulan data, penulis melakukan beberapa teknik pengumpulan data, yaitu teknik wawancara, dokumentasi, dan studi kepustakaan. Teknik wawancara yang dipilih yaitu wawancara semi terstruktur. Wawancara dilakukan penulis kepada pegawai Bagian Seksi Penagihan KPP Pratama Denpasar Barat yaitu Jurusita Pajak. Dokumentasi dilakukan dengan menggunakan dokumen-dokumen serta data terkait penagihan pajak yang disediakan oleh KPP Pratama Denpasar Barat sebagai data sekunder yang kemudian dianalisis untuk membantu dalam penarikan kesimpulan. Studi kepustakaan dilakukan dengan membaca peraturan perundang-undangan terkait, buku, jurnal ilmiah sebagai referensi. Teknik ini digunakan untuk mendapatkan data sekunder sebagai pembanding antara teori dengan praktiknya dalam lapangan dan sebagai dasar bagi penulis dalam memberikan pendapat. 


\section{HASIL PENELITIAN}

\subsection{Ketentuan Penagihan Pajak di KPP Pratama} Denpasar Barat Pada Masa Pandemi COVID-19

Secara umum, ketentuan penagihan pajak di KPP Pratama Denpasar Barat pada masa pandemi COVID-19 khususnya pada bulan Maret-Desember 2020 masih tetap dilaksanakan sesuai dengan peraturan perundang-undangan perpajakan yang berlaku. Adapun aturan-aturan tersebut, yaitu:

1. Undang-Undang Nomor 6 Tahun 1983 tentang Ketentuan Umum dan Tata Cara Perpajakan sebagaimana telah beberapa kali diubah terakhir dengan Undang-Undang Nomor 11 Tahun 2020.

2. Undang-Undang Nomor 19 Tahun 2000 tentang Perubahan atas Undang-Undang Nomor 19 Tahun 1997 tentang Penagihan Pajak dengan Surat Paksa.

3. Peraturan Pemerintah Nomor 135 Tahun 2000 tentang Tata Cara Penyitaan Dalam Rangka Penagihan Pajak dengan Surat Paksa.

4. Peraturan Pemerintah Nomor 74 Tahun 2011 tentang Tata Cara Pelaksanaan Hak dan Pemenuhan Kewajiban Perpajakan.

5. Peraturan Menteri Keuangan Nomor 189/PMK.03/2020 tentang Tata Cara Pelaksanaan Penagihan Pajak atas Jumlah Pajak yang Masih Harus Dibayar.

6. Surat Edaran Direktur Jenderal Pajak Nomor SE29/PJ/2012 tentang Kebijakan Penagihan Pajak.

7. Surat Edaran Direktur Jenderal Nomor SE01/PJ/2020 tentang Pelunasan Utang Pajak dan Biaya Penagihan Pajak yang Menjadi Kewajiban Penanggung Pajak atas Wajib Pajak Badan Dalam Rangka Penagihan Pajak dengan Surat Paksa.

8. Surat Edaran Direktur Jenderal Pajak Nomor SE09/PJ/2020 tentang Petunjuk Pelaksanaan Pencegahan Dalam Rangka Penagihan Pajak.

9. Surat Edaran Direktur Jenderal Pajak Nomor SE34/PJ/2020 tentang Panduan Teknis Pelaksanaan Tugas Dalam Tatanan Kenormalan Baru di Lingkungan Direktorat Jenderal Pajak.

10. Nota Dinas Nomor ND-633/PJ.04/2020 perihal Penegasan terkait Kegiatan Pemeriksaan dan Penagihan Sehubungan dengan Pelaksanaan SE13/PJ/2020.

11. Nota Dinas Nomor ND-1153/PJ.04/2020 perihal Penegasan Pelaksanaan Kegiatan Pemeriksaan dan Penagihan.

Berdasarkan hasil wawancara dengan Putu Gede Yudha, Jurusita Pajak KPP Pratama Denpasar Barat, dijelaskan bahwa selama masa pandemi COVID-19 ketentuan penagihan pajak sebagaimana pada penjelasan diatas dijalankan tidak "kaku" sepenuhnya mengikuti ketentuan tersebut. KPP Pratama Denpasar Barat lebih menekankan kepada pendekatan persuasif atau lebih bersifat "membujuk" agar wajib pajak mau melunasi utang pajaknya.

Hal ini juga merupakan tindak lanjut dari dikeluarkannya Nota Dinas Nomor ND633/PJ.04/2020 perihal Penegasan terkait Kegiatan
Pemeriksaan dan Penagihan Sehubungan dengan Pelaksanaan SE-13/PJ/2020 yang meminta Jurusita agar melakukan tindakan penagihan persuasif melalui surat menyurat, telepon, email, chat dan saluran online lainnya.

Adanya pendekatan persuasif ini yang sedikit membedakan ketentuan bagaimana tindakan penagihan pajak pada masa pandemi dijalankan dibandingkan pada tahun-tahun kemarin disaat situasi normal. Tindakan persuasif tidak begitu saja dilakukan oleh Jurusita, tetapi juga disesuaikan dengan hasil profiling wajib pajak yang telah dilakukan oleh Jurusita Pajak.

Berdasarkan penjelasan diatas, terlihat bahwa ketentuan penagihan pajak aktif di KPP Pratama Denpasar Barat selama masa pandemi COVID-19 tetap berdasarkan kepada Undang-Undang Penagihan Pajak dengan Surat Paksa beserta aturan-aturan pelaksanaannya. Namun ketentuan tersebut dibarengi dengan nota dinas maupun surat edaran yang dikeluarkan Direktorat Jenderal Pajak selama masa pandemi yang menekankan pada tindakan penagihan pajak menggunakan pendekatan persuasif. Ketentuan tersebut juga memberikan keleluasaan kepada Jurusita Pajak dalam menjalankan penagihan pajak. Diskresi Jurusita menjadi hal yang penting untuk menentukan tindakan penagihan pajak yang akan diberikan kepada wajib pajak.

Dasar yang dijadikan oleh Jurusita dalam menentukan tindakan penagihan adalah hasil dari profiling wajib pajak dan itikad baik yang diberikan oleh wajib pajak. Mengajak wajib pajak untuk bertemu dan berdiskusi terkait kemampuan finansial untuk melunasi utang pajaknya menjadi fokus utama penyelesaian dari tindakan penagihan pajak aktif yang berjalan. Hal ini lah yang cukup membedakan ketentuan penagihan pajak di KPP Pratama Denpasar Barat pada masa pandemi COVID-19 dari tahun-tahun sebelumnya disaat situasi normal.

\subsection{Analisis Pelaksanaan Penagihan Pajak di KPP Pratama Denpasar Barat Pada Masa Pandemi COVID-19}

Dalam melakukan analisis pelaksanaan penagihan pajak di KPP Pratama Denpasar Barat pada masa pandemi COVID-19 khususnya pada bulan Maret hingga Desember 2020, penulis mengukur tingkat efektivitas pelaksanaan dengan membandingkan target pencairan piutang pajak dari tindakan penagihan pajak dengan realisasinya.

Selanjutnya penulis membandingkan hasil persentase tersebut dengan hasil persentase pada dua tahun sebelumnya. Selain itu penulis juga menganalisis data dengan menyesuaikan hasil wawancara dengan Jurusita Pajak KPP Pratama Denpasar Barat. Berikut merupakan tabel jumlah target dan realisasi pencairan piutang pajak dari tindakan penagihan pajak khususnya bulan Maret-Desember Tahun 2018-2020. 
Tabel 2.Persentase Efektivitas Penagihan Pajak KPP Pratama Denpasar Barat

\begin{tabular}{|c|c|c|c|}
\hline $\begin{array}{c}\text { Tahun } \\
\text { Pajak } \\
\text { (Mar- } \\
\text { Des) }\end{array}$ & $\begin{array}{c}\text { Target } \\
\text { Pencairan }\end{array}$ & $\begin{array}{c}\text { Realisasi } \\
\text { Pencairan }\end{array}$ & $\begin{array}{c}\text { Perse- } \\
\text { ntase }\end{array}$ \\
\hline 2018 & 25.147 .464 .853 & 21.510 .128 .738 & $\begin{array}{c}85,54 \\
\%\end{array}$ \\
\hline 2019 & 21.814 .607 .895 & 14.794 .367 .425 & $\begin{array}{c}67,82 \\
\%\end{array}$ \\
\hline 2020 & 16.339 .225 .483 & 6.141 .008 .585 & $\begin{array}{c}37,58 \\
\%\end{array}$ \\
\hline
\end{tabular}

Sumber: Diolah penulis dari KPP Pratama Denpasar Barat

Dari tabel 2 menunjukan bahwa persentase efektivitas penagihan pajak di KPP Pratama Denpasar Barat dari tahun pajak 2018-2020 cenderung mengalami penurunan yang cukup signifikan. Pada tahun 2020, di saat Indonesia dilanda pandemi COVID19 , target maupun realisasi pencairan piutang pajak dari tindakan penagihan pajak mengalami penurunan yang cukup signifikan dari dua tahun sebelumnya. Seksi Penagihan KPP Pratama Denpasar Barat memiliki target sebesar Rp. 16.339.225.483 dengan realisasi yang cukup jauh, yaitu hanya sebesar Rp. 6.141.008.585. Sehingga jika dibandingkan hanya memiliki persentase efektivitas sebesar 37, 58\% dari target. Angka ini jika digolongkan ke kategori efektivitas sesuai Kepmendagri No 690.900.327 Tahun 1996 dan IKU Direktorat Jenderal Pajak maka tergolong ke kategori tidak efektif. Hal ini menunjukan bahwa pandemi COVID-19 memiliki pengaruh terhadap tingkat efektivitas pelaksanaan penagihan pajak ditinjau dari pencairan piutang pajaknya.

Sependapat dengan penjelasan diatas, Putu Gde Yudha, salah satu Jurusita Pajak di KPP Pratama Denpasar Barat juga mengatakan bahwa apabila parameter efektivitas penagihan pajak diukur dengan tingkat pencairan piutang pajak maka memang di tahun 2020 pada masa pandemi seperti sekarang, efektivitas penagihan pajak nya menurun dibandingkan dengan tahun-tahun sebelumnya. Namun disisi lain, Putu Gde Yudha juga menyampaikan bahwa pada masa pandemi COVID-19 seperti sekarang, pencairan piutang pajak sebenarnya tidak bisa sepenuhnya digunakan untuk mengukur tingkat efektivitas. Menurut pendapat narasumber, sepanjang pelaksanaan masing-masing tindakan penagihan pajak dapat dilaksanakan memenuhi target, maka hal tersebut juga bisa dikatakan pelaksanaan penagihan pajak berjalan efektif

Untuk mengetahui hal tersebut, berikut merupakan data beserta hasil analisis penulis terhadap pelaksanaan masing-masing tindakan penagihan pajak di KPP Pratama Denpasar Barat.
1. Penagihan Pajak dengan Surat Paksa

Tabel 3. Target dan Realisasi Penagihan Pajak dengan Surat Paksa

\begin{tabular}{|c|c|c|l|l|}
\hline Tahun & $\begin{array}{c}\text { Target } \\
\text { lembar }\end{array}$ & $\begin{array}{l}\text { Realisasi } \\
\text { lembar }\end{array}$ & $\begin{array}{l}\text { Persent } \\
\text { ase }\end{array}$ & $\begin{array}{l}\text { Pencairan } \\
\text { Piutang Pajak }\end{array}$ \\
\hline 2018 & 411 & 792 & $192 \%$ & 4.761 .848 .074 \\
\hline 2019 & 650 & 915 & $140,8 \%$ & 616.278 .118 \\
\hline 2020 & 559 & 496 & $88,7 \%$ & 2.515 .817 .246 \\
\hline
\end{tabular}

Sumber: Diolah penulis dari KPP Pratama Denpasar Barat

Dari tabel 3 menunjukan bahwa pelaksanaan penagihan pajak dengan Surat Paksa dari tahun 20182020 mengalami penurunan tingkat efektivitas pencapaian target. Dari tiga tahun yang dibandingkan terlihat bahwa tahun 2020 menjadi satu-satunya tahun yang jumlah realisasi penyampaiannya tidak melampau target. Namun dengan persentase $88,7 \%$ dari target dapat dikatakan sudah cukup efektif.

2. Penagihan Pajak dengan Surat Perintah Melaksanakan Penyitaan (SPMP)

Tabel 4. Target dan Realisasi Penagihan Pajak dengan SPMP

\begin{tabular}{|l|c|c|l|l|}
\hline Tahun & $\begin{array}{l}\text { Target } \\
\text { Lembar }\end{array}$ & $\begin{array}{l}\text { Realisasi } \\
\text { Lembar }\end{array}$ & $\begin{array}{l}\text { Perse } \\
\text { ntase }\end{array}$ & $\begin{array}{l}\text { Pencairan } \\
\text { Piutang Pajak }\end{array}$ \\
\hline 2018 & 30 & 30 & $100 \%$ & 7.652 .456 .183 \\
\hline 2019 & 30 & 28 & $\begin{array}{l}93,3 \\
\%\end{array}$ & 9.699 .817 .241 \\
\hline 2020 & 30 & 38 & $\begin{array}{l}126,7 \\
\%\end{array}$ & 872.518 .851 \\
\hline
\end{tabular}

Sumber: Diolah penulis dari KPP Pratama Denpasar Barat

Pada tahun 2020 terlihat bahwa dari segi pelaksanaan SPMP terlihat efektif karena mampu melampaui target dari yang telah ditetapkan. Namun meskipun demikian, nyatanya piutang pajak yang terealisasi dari SPMP jumlahnya paling kecil dibandingkan dengan tahun sebelumnya. Tentunya hal ini bisa saja dikarenakan situasi pandemi yang membuat ekonomi masyarakat menurun.

3. Penagihan Pajak dengan Pemblokiran

Tabel 5. Target dan Realisasi Penagihan Pajak dengan Pemblokiran

\begin{tabular}{|l|c|c|l|c|}
\hline Tahun & Target & Realisasi & $\begin{array}{l}\text { Persen } \\
\text { tase }\end{array}$ & $\begin{array}{l}\text { Pencairan } \\
\text { Piutang Pajak }\end{array}$ \\
\hline 2018 & 6 & 30 & $500 \%$ & 7.652 .456 .183 \\
\hline 2019 & 8 & 21 & $\begin{array}{l}262,5 \\
\%\end{array}$ & 3.222 .346 .780 \\
\hline 2020 & 7 & 9 & $\begin{array}{l}128,6 \\
\%\end{array}$ & 205.797 .005 \\
\hline
\end{tabular}

Sumber: Diolah penulis dari KPP Pratama Denpasar Barat

Pada tahun 2020, terdapat penurunan yang sangat signifikan dalam pelaksanaan pemblokiran. Penurunan jumlah pelaksanaan pemblokiran disertai dengan besaran penurunan nilai pencairan dari pemblokiran itu sendiri, yaitu sebesar Rp. 205.797.005. Hal ini menunjukan bahwa baik dari sisi pelaksanaan hingga pencairan piutang pajak, 
penagihan pajak dengan pemblokiran tidak cukup efektif dibandingkan dengan tahun-tahun kemarinnya.

4. Penagihan Pajak dengan Lelang

Tabel 6. Target dan Realisasi Penagihan Pajak dengan Lelang

\begin{tabular}{|l|l|l|l|l|}
\hline Tahun & Target & Realisasi & $\begin{array}{l}\text { Persent } \\
\text { ase }\end{array}$ & $\begin{array}{l}\text { Pencairan } \\
\text { Piutang } \\
\text { Pajak }\end{array}$ \\
\hline 2018 & 1 & 1 & $100 \%$ & 6.090 .000 \\
\hline 2019 & 3 & 7 & $233,3 \%$ & $\begin{array}{l}181.537 .43 \\
3\end{array}$ \\
\hline 2020 & 1 & 2 & $200 \%$ & $\begin{array}{l}851.571 .71 \\
9\end{array}$ \\
\hline
\end{tabular}

Sumber: Diolah penulis dari KPP Pratama Denpasar Barat

Tabel 6 menunjukan bahwa pelaksanaan penagihan pajak dengan lelang pada tahun 2020 memiliki tingkat pencapaian yang tinggi dengan tingkat persentase sebesar 200\%. Tingkat pencapaian pelaksanaan yang melebihi target ini juga diikuti dengan pencairan piutang pajak yang berhasil dilakukan, dengan jumlah yang tertinggi dibandingkan dua tahun sebelumnya. Hal ini menunjukan bahwa meskipun pada tahun 2020 terhalang dengan adanya pandemi COVID-19, seksi penagihan pajak KPP Pratama Denpasar Barat tetap bisa melaksanakan penagihan pajak lelang dengan efektif. Hal tersebut dikarenakan pelaksanaan lelang bisa melebihi target pelaksanaan.

Dari hasil analisis-analisis diatas, apabila dilihat dari pelaksanaan masing-masing tindakan penagihan pajak, terlihat bahwa memang pada tahun 2020 (Maret-Desember) rata-rata pelaksanaan penagihan pajak berjalan efektif. Hal ini dikarenakan cukup banyak tindakan penagihan pajak yang bisa dilakukan melampaui target yang ditetapkan, yaitu penagihan dengan Surat Paksa, SPMP, Pemblokiran dan Pelaksanaan Lelang. Meskipun demikian, nyatanya tindakan pelaksanaan tersebut tidak seefektif dua tahun sebelumnya dalam hal mencairkan piutang pajak dari tindakan penagihan tersebut. Hal ini kembali menunjukan bahwa meskipun proses pelaksanaan penagihan telah dilakukan dengan baik, namun tidak diimbangi dengan kemampuan wajib pajak atau penanggung pajak melunasi utang pajak nya akibat ekonomi masyarakat menurun pada masa pandemi COVID-19.

Persoalan ini disampaikan juga saat wawancara dengan Jurusita Pajak KPP Pratama Denpasar Barat. Narasumber menjelaskan bahwa pada masa pandemi COVID-19, tidak sedikit wajib pajak atau penanggung pajak yang bersedia untuk melunasi seluruh utang pajak yang dimiliki dibandingkan harus mengikuti tindakan penagihan yang semakin panjang, namun hal tersebut justru tidak diimbangi dengan kemampuan finansial/keuangan wajib pajak untuk melunasi keseluruhan utang pajaknya.

\subsection{Hambatan KPP Pratama Denpasar Barat dalam Melaksanakan Tindakan Penagihan Pajak}

Dalam menjalankan tindakan penagihan pajak khususnya pada masa pandemi COVID-19 tidak sedikit hambatan-hambatan yang dilalui oleh Jurusita Pajak, terutama pada saat proses penagihan pajak yang mengharuskan adanya pertemuan dengan wajib pajak. Tentunya ada tantangan-tantangan yang berbeda dan baru dialami oleh Jurusita Pajak dibandingkan dengan tahun-tahun sebelumnya disaat situasi normal.

Terlebih lagi dengan diterbitkannya Surat Edaran Direktorat Jenderal Pajak Nomor SE-34/PJ/2020 tentang Panduan Teknis Pelaksanaan Tugas Dalam Tatanan Kenormalan Baru di Lingkungan Direktorat Jenderal Pajak yang mengharuskan Jurusita Pajak menjalankan proses penagihan pajak menyesuaikan dengan situasi pandemi COVID-19.

Berdasarkan hasil wawancara dengan Putu Gde Yudha, salah satu Jurusita Pajak di KPP Pratama Denpasar Barat, adapun beberapa hambatanhambatan yang dilalui dalam pelaksanaan penagihan pajak pada masa pandemi COVID-19 adalah sebagai berikut.

1. Ketidakjelasan alamat dan nomor telepon wajib pajak.

Salah satu kendala yang dialami oleh Jurusita Pajak dalam melaksanakan penagihan pajak adalah alamat wajib pajak yang tidak jelas. Tidak jelas yang dimaksud dalam hal ini memiliki banyak maksud, diantaranya alamat wajib pajak yang ditulis tidak secara mendetail, alamat yang ditulis tidak sesuai dengan tempat wajib pajak, dan bahkan termasuk wajib pajak yang sudah pindah alamat namun belum melakukan pembaruan data alamat.

Alamat yang tidak jelas ini juga terkadang dipersulit dengan nomor telepon wajib pajak yang tidak aktif ataupun salah. Putu Gde Yudha, Jurusita Pajak KPP Pratama Denpasar Barat, menjelaskan bahwa ketika Jurusita kesulitan dalam mencari alamat, maka menghubungi wajib pajak merupakan salah satu cara agar mengetahui alamat terbaru wajib pajak, namun tidak sedikit juga nomor telepon wajib pajak yang terdaftar dalam SIDJP merupakan nomor yang tidak aktif.

2. Ketakutan wajib pajak untuk bertatap muka secara langsung.

Pada masa pandemi COVID-19 seperti sekarang, hal ini dapat dikatakan sebagai hambatan baru yang dirasakan oleh Jurusita Pajak dalam menjalankan tindakan penagihan pajak. Sebagaimana kita ketahui bahwa sesuai dengan aturan perundang-undangan penagihan pajak dengan Surat Paksa dijelaskan bahwa Surat Paksa wajib disampaikan secara langsung kepada wajib pajak. Adanya pembatasan oleh pemerintah untuk bertatap muka secara langsung membuat tidak sedikit wajib pajak yang takut untuk menerima orangorang yang datang ke rumah wajib pajak.

Hal ini tentu menjadi suatu hambatan dan dilema bagi Jurusita. Tentunya bukanlah hal yang salah 
ketika wajib pajak tidak ingin bertatap muka langsung dengan orang lain mengingat hal tersebut juga merupakan anjuran dari pemerintah untuk menghindari penyebaran virus COVID-19 yang semakin luas.

3. Wajib pajak tidak kooperatif.

Dalam menjalankan penagihan pajak, tidak sedikit oknum wajib pajak yang tidak kooperatif kepada Jurusita. Tidak kooperatif dalam artian tidak mau mengikuti tindakan penagihan sesuai dengan peraturan perundang-undangan. Salah satu contoh tindakan yang tidak kooperatif yang terjadi di KPP Pratama Denpasar Barat, yaitu pada saat Jurusita Pajak akan melakukan tindakan pemblokiran terhadap rekening wajib pajak. Seringkali wajib pajak tidak mau mengakui keseluruhan rekening-rekening Bank yang dimilikinya padahal hal tersebut sangat diperlukan oleh Jurusita Pajak dalam hal wajib pajak tidak memiliki aset tetap yang dapat dilakukan penyitaan.

4. Ketidakjelasan dan ketidakpastian protokol kesehatan.

Pada awal-awal masa pandemi COVID-19 di Indonesia, tepatnya bulan Maret-April 2020, belum ada kepastian mengenai protokol kesehatan yang tepat dan pasti sehingga membuat pelaksanaan penagihan pajak di KPP Pratama Denpasar barat pun sedikit terhambat khususnya dalam penerbitan dan penyampaian Surat Paksa.

Jurusita Pajak KPP Pratama Denpasar Barat mengatakan bahwa memang karena isu pandemi yang heboh pada saat itu disertai dengan ketidakjelasan protokol kesehatan yang sesuai, membuat KPP Pratama Denpasar barat memutuskan untuk sedikit memperlambat tindakan penagihan pajaknya. KPP Pratama Denpasar Barat pada saat itu lebih memfokuskan kepada penerbitan surat teguran kepada wajib pajak yang mana hal tersebut tidak mengharuskan adanya tatap muka secara langsung dan dapat dikirimkan melalui kantor pos.

5. Penurunan daya beli atau kemampuan finansial masyarakat.

Hambatan lainnya dalam proses penagihan pajak aktif di KPP Pratama Denpasar Barat selama masa pandemi COVID-19, yaitu sulitnya untuk melakukan pelelangan dengan harga yang maksimal terhadap asetaset wajib pajak yang disita. Putu Gde Yudha, Jurusita KPP Pratama Denpasar Barat, mengatakan bahwa meskipun Jurusita berhasil melakukan penyitaan terhadap aset wajib pajak namun yang lebih penting adalah bagaimana bisa mencairkan aset sitaan tersebut sehingga bisa masuk ke kas negara sebagai bentuk penerimaan negara. Daya beli/kemampuan finansial masyarakat yang turun akibat pandemi, diakui oleh Jurusita sangat berpengaruh terhadap penawaranpenawaran masyarakat umum terhadap aset hasil penyitaan. Akibatnya pencairan yang didapatkan dari proses pelelangan pun sering jauh dari target yang diinginkan.

\subsection{Upaya KPP Pratama Denpasar Barat Menyelesaikan Hambatan dalam Penagihan Pajak}

Berikut merupakan upaya-upaya yang telah dilakukan KPP Pratama Denpasar Barat khususnya seksi penagihan pajak dalam menyelesaikan hambatan selama melakukan penagihan pajak di masa pandemi COVID-19.

1. Menghubungi wajib pajak melalui media telepon.

Ketika dihadapkan dengan alamat wajib pajak yang tidak jelas saat akan melakukan penagihan pajak ke lokasi wajib pajak, upaya yang dilakukan Jurusita yaitu dengan menghubungi wajib pajak dengan media telepon. Namun disampaikan juga bahwa untuk mengurangi resiko tidak bertemu wajib pajak di lokasi, sering kali Jurusita memilih untuk menghubungi wajib pajak terlebih dahulu atau mengkonfirmasi keberadaan wajib pajak sebelum berangkat ke lokasi untuk melaksanakan tindakan penagihan pajak. Hal ini juga sebagai bentuk tindak lanjut dari terbitnya Nota Dinas Nomor ND-633/PJ.04/2020.

2. Berdiskusi melalui media telepon.

Pada situasi COVID-19 seperti saat ini, terlebih saat awal-awal dinyatakan sebagai pandemi, memang sangat sulit untuk bisa bertatap muka secara langsung dengan wajib pajak. Oleh karenanya upaya yang dilakukan oleh Jurusita untuk tetap dapat menjalankan tindakan penagihan pajak aktif, yaitu dengan meminta kepada wajib pajak untuk segera menghubungi Jurusita Pajak. Selanjutnya, Jurusita pun akan menyampaikan tindakan penagihan pajak yang akan dilakukan hanya melalui telepon.

Jurusita merasa bahwa tindakan ini merupakan tindakan yang paling tepat untuk dilakukan pada situasi seperti ini terlebih diperkuat dengan adanya Nota Dinas Nomor ND-633/PJ.04/2020 dan Surat Edaran Direktur Jenderal Pajak Nomor SE-34/PJ/2020 yang diterbitkan oleh Direktur Jenderal Pajak.

3. Bekerja sama dengan Pihak Ketiga.

Untuk mengatasi beberapa oknum wajib pajak yang tidak kooperatif saat dilakukan tindakan penagihan pajak, upaya yang dilakukan Jurusita, yaitu bekerjasama dengan pihak ketiga. Seperti yang sudah dijelaskan pada bagian hambatan diatas, bahwa tidak sedikit wajib pajak yang tidak memberi tahu keseluruhan rekening yang dimilikinya. Sehingga untuk tetap mengupayakan agar bisa memblokir rekening wajib pajak, Jurusita Pajak melakukan kerjasama dengan pihak Bank untuk membantu mencari rekening wajib pajak.

4. Memfokuskan penagihan pajak dengan Surat Teguran.

Upaya yang dilakukan oleh KPP Pratama Denpasar Barat pada awal-awal masa pandemi COVID19 , yaitu dengan memfokuskan penagihan pajak melalui penerbitan surat teguran. Kebijakan ini diambil oleh KPP Pratama Denpasar Barat untuk melindungi pegawainya dari kemungkinan terpapar virus COVID-19 akibat bertemu banyak orang. Selain itu, upaya yang dilakukan

juga yaitu melakukan penagihan pajak dengan mengundang wajib pajak untuk hadir langsung ke kantor pajak untuk membicarakan utang pajak yang 
dimiliki. Upaya ini setidaknya cukup membuat tindakan penagihan pajak di KPP Pratama Denpasar Barat tetap berjalan meskipun pada situasi dan kondisi yang sulit.

5. Memberikan penawaran diluar Proses Lelang.

Dengan menurunnya daya beli masyarakat, untuk bisa secepat mungkin mencairkan aset sitaan wajib pajak menjadi kas yang masuk ke penerimaan negara, salah satu upaya yang dilakukan oleh Jurusita Pajak, yaitu dengan mempromosikan aset sitaan wajib pajak diluar dari proses lelang. Hal ini dilakukan guna memberikan informasi kepada pembeli secepat mungkin dengan menginformasikan tetap dengan harga yang sesuai dengan harga wajarnya. Tindakan ini dirasa oleh Jurusita merupakan salah satu cara yang efektif dibandingkan dengan menunggu waktu pengumuman lelang yang cukup lama sejak aset telah disita.

\section{KESIMPULAN DAN SARAN}

Berdasarkan data, fakta, hasil wawancara dengan Jurusita Pajak, dan analisis efektivitas pelaksanaan penagihan pajak di KPP Pratama Denpasar Barat pada masa pandemi COVID-19, maka penulis dapat menarik kesimpulan sebagai berikut.

1. Pelaksanaan penagihan pajak di KPP Pratama Denpasar Barat pada masa pandemi COVID-19 dilaksanakan sesuai dengan ketentuan perundangundangan perpajakan, yaitu Undang-Undang Nomor 19 Tahun 2000 tentang Penagihan Pajak dengan Surat Paksa dan peraturan pelaksanaannya, meliputi: Peraturan Pemerintah, Peraturan Menteri Keuangan, Surat Edaran Direktur Jenderal Pajak, hingga Nota Dinas. Terdapat sedikit perbedaan ketentuan dibandingkan dengan dua tahun sebelumnya. Pada masa pandemi COVID-19, KPP Pratama Denpasar Barat menjalankan ketentuan dengan mengutamakan tindakan penagihan persuasif.

2. Efektivitas pelaksanaan penagihan pajak di KPP Pratama Denpasar Barat pada masa pandemi COVID-19, jika dinilai berdasarkan perbandingan antara realisasi pencairan piutang pajak dengan target, maka dapat dikatakan bahwa tergolong tidak efektif dengan tingkat persentase sebesar 37, 58\% dari target. Persentase efektivitas ini jauh menurun dibandingkan dengan dua tahun sebelumnya pada saat situasi normal, yaitu pada tahun 2018 sebesar 85,54\% dan pada tahun 2019 sebesar 67,82\%. Dari persentase ini dapat menggambarkan bahwa pada tahun 2020 menjadi tingkat persentase efektivitas yang terendah.

3. Hambatan KPP Pratama Denpasar Barat dalam melaksanakan penagihan pajak pada masa pandemi COVID-19 diantaranya, yaitu ketidakjelasan alamat dan nomor telepon wajib pajak yang mengakibatkan Jurusita Pajak kesulitan dalam menjalankan proses penagihan pajak.
Berikutnya, ketidakpastian protokol kesehatan pada awal-awal masa pandemi COVID-19 dan ketakutan wajib pajak untuk bertatap muka secara langsung menghambat tindakan penagihan pajak khususnya penyampaian Surat Paksa. Penurunan kemampuan finansial masyarakat dan adanya oknum wajib pajak yang tidak kooperatif untuk mengikuti setiap tindakan penagihan pajak juga menjadi hambatan Jurusita dalam melakukan pencairan piutang pajak melalui tindakan penagihan.

4. Upaya yang dilakukan KPP Pratama Denpasar Barat dalam menghadapi hambatan selama pelaksanaan penagihan pajak pada masa pandemi COVID-19 diantaranya, yaitu menghubungi wajib Pajak melalui media telepon ketika kesulitan menemukan alamat wajib pajak. Juru sita juga memilih untuk berdiskusi melalui media telepon dan memfokuskan penagihan pajak dengan Surat Teguran untuk mengurangi tatap muka langsung saat akan menyampaikan Surat Paksa. Upaya lain, dengan bekerjasama kepada pihak ketiga seperti bank dan memberikan penawaran kepada masyarakat atas aset sitaan mendahului pengumuman lelang untuk bisa memaksimalkan pencairan piutang pajak.

\section{DAFTAR PUSTAKA (REFERENCES)}

Alijoyo. (2000). Effectiveness. Jakarta: Ghalia.

Direktorat Jenderal Pajak. (2020). Laporan Kinerja Direktorat Jenderal Pajak 2019. Jakarta: Direktorat Jenderal Pajak.

Direktorat Jenderal Pajak. (2020). Nota Dinas Nomor ND-1153/PJ.04/2020. Jakarta: Direktorat Pemeriksaan dan Penagihan.

Direktorat Jenderal Pajak. (2020). Nota Dinas Nomor ND-633/PJ.04/2020. Jakarta: Direktorat Pemeriksaan dan Penagihan.

Direktorat Jenderal Pajak. (2020). Surat Edaran Direktur Jenderal Pajak Nomor SE-34/PJ/2020 tentang Panduan Teknis Pelaksanaan Tugas Dalam Tatanan Kenormalan Baru di Lingkungan Direktorat Jenderal Pajak. Jakarta.

Hadi, H. (2001). Dasar-Dasar Penagihan Pajak. Jakarta: PT. Raja Grafindo Persada.,,

Handoko, T. H. (2001). Manajemen Personalia dan Sumber Daya Manusia. BPFE.

Harahap, M. A. (2020, Agustus). penagihan-pajak-dimasa-pandemi. Retrieved from www.pajak.go.id: https://www.pajak.go.id/id/artikel/penagihanpajak-di-masa-pandemi

Hasan, M. I. (2002). Pokok-Pokok Materi Metodologi Penelitian \& Aplikasinya. Bogor: Ghalia Indonesia.

Hasbi Rifqiansyah, M. S. (2014). Analisis Efektivitas dan Kontribusi Penagihan Pajak Aktif terhadap Pencairan Tunggakan Pajak (Studi pada Kantor 
Pelayanan Pajak Pratama Malang Utara). Malang: Jurnal Administrasi Bisnis Vol.15 No.1,110.

Lembaga Ilmu Pengetahuan Indonesia. (2020, Juni 30). survei-kinerja-umkm-di-masa-pandemi-covid19. Retrieved from lipi.go.id: http://lipi.go.id/berita/survei-kinerja-umkm-dimasa-pandemi-covid19/22071

Mardiasmo. (2006). Perpajakan. Yogyakarta: Andi.

Nazir, M. (2013). Metode Penelitian. Bogor: Ghalia Indonesia.

Pemerintah Indonesia. (2008). Undang-Undang Republik Indonesia Nomor 36 Tahun 2008 Tentang Perubahan Keempat atas Undang Undang Nomor 7 Tahun 1983 Tentang Pajak Penghasilan.

Republik Indonesia. (1996). Kepmendagri No 690.900.327 tentang Pedoman Penilaian Kinerja Keuangan. Jakarta: Sekretariat Negara.

Republik Indonesia. (2000). Peraturan Pemerintah Republik Indonesia Nomor 135 tahun 2000 Tentang Tata Cara Penyitaan Dalam Rangka Penagihan Pajak Dengan Surat Paksa. Jakarta: Kesekretariatan Negara Republik Indonesia.

Republik Indonesia. (2000). Undang-Undang Nomor 19 tahun 2000 tentang Perubahan Atas UndangUndang Nomor 19 Tahun 1997 Tentang Penagihan Pajak dengan Surat Paksa. Jakarta: Sekretariat Negara.

Republik Indonesia. (2014). Peraturan Direktur Jenderal Pajak PER -24/PJ/204 tentang Tata Cara Pelaksanaan Pemblokiran dan Penyitaan Harta Kekayaan Penanggung Pajak yang Tersimpan Pada Bank Dalam Rangka Penagihan Pajak dengan Surat Paksa. Jakarta: Direktur Jenderal Pajak.

Rusdji, M. (2005). PPSP Penagihan Pajak dengan Surat Paksa. Jakarta: Indeks.

Soemitro, R. (1991). Pengantar Singkat Hukum Pajak. Bandung: Eresco.

Suandy, E. (2011). Hukum Pajak. Jakarta: Salemba Empat.

Sugiyono, P. (2011). Metode Penelitian Kuantitatif Kualitatif dan R\&D. Bandung: Alfabeta.

Ulum, M. I. (2004). Akuntansi Sektor Publik. Malang: UMM Press.

Utara, A. S. (2011). Modul Pengantar Hukum Pajak Diklat Teknis Substantif (DTS) Dasar Pajak I. Jakarta: Kementerian Keuangan Republik Indonesia .

Waluyo. (2002). Perpajakan Indonesia. Jakarta: Salemba Empat.

Wirawan B Suhartono, I. d. (2013). Perpajakan. Jakarta: Mitra Wacana.

Zulvina, S. (2011). Bahan Ajar Pengantar Hukum Pajak. Jakarta: Sekolah Tinggi Akuntansi Negara.

Zuraida, I. (2011). Bahan Ajar Penagihan dan Sengketa Pajak. Jakarta: Sekolah Tinggi Akuntansi Negara 